\title{
Clark's Nutcracker in the Cypress Hills
}

by Fred G. Bard, Saskatchewan Museum of Natural History, Regina

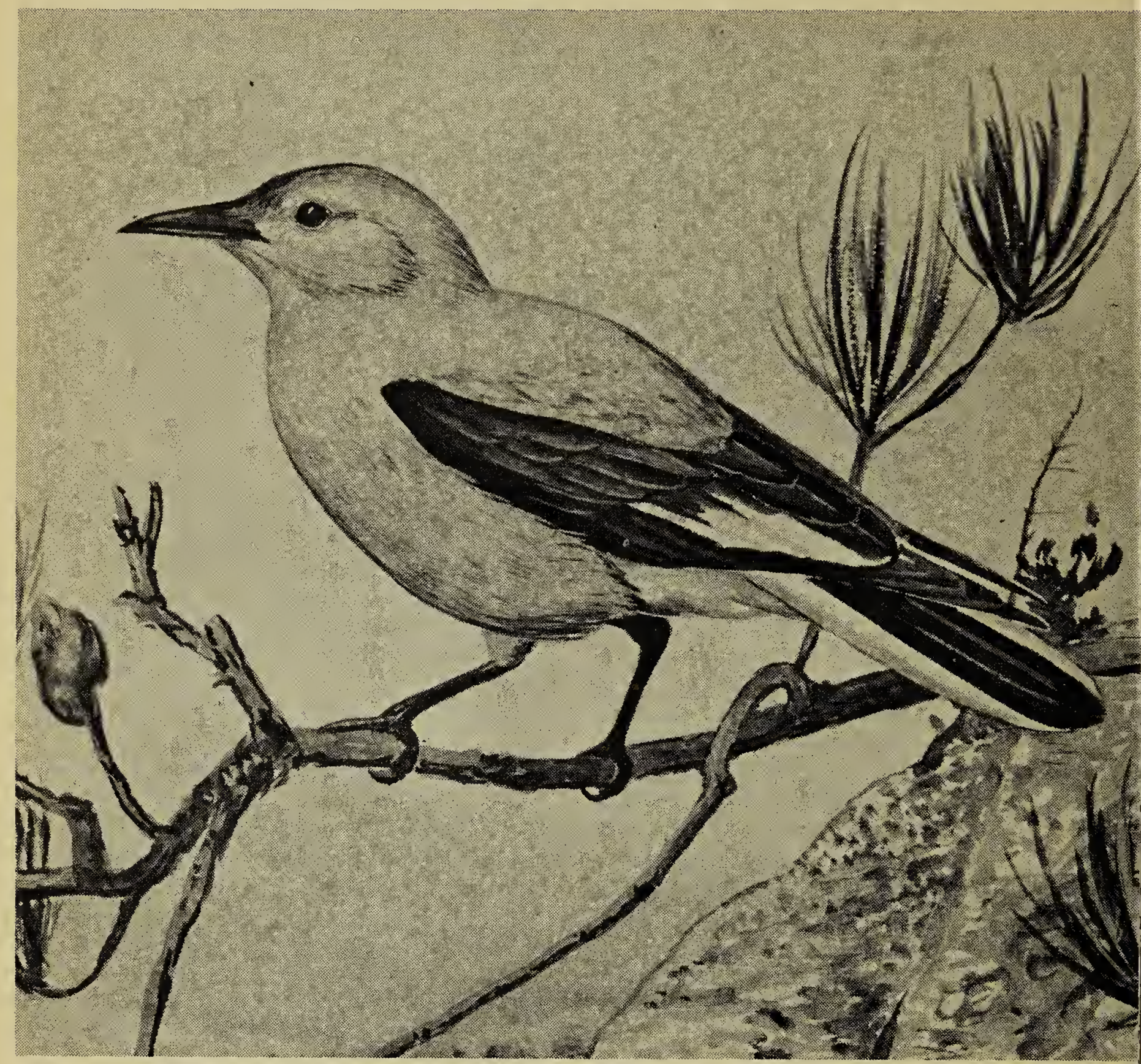

Fred Lahrman's sketch shows a Clark's Nutcracker (Nucifraga columbiana) in the setting where I had the good fcrtune to see this bird last fall. On October 8, 1963, accompanied by C. S. Brown and by Barry Tether, conservation officer stationed at Cypress Park, I was taking photographs at the "Conglomerate Cliffs" in the west blcck of the Cypress Hills overlooking Battle Creek. I had just finished adjusting my camera for a picture when I realized that an unusual bird had come to perch briefly on a nearby tree. It did not stay long enough for me to photcgraph it, but befcre it flew overhead and off into the Battle Creek Valley, I had a good view of the Clark's Nutcracker-the first I have ever seen in Saskatchewan.
As far as I know, there are only three records of Clark's Nutcracker in Saskatchewan, and these all come -as might be expected, from this southwest corner of the province. When the most recent reccrd, of one seen August 18, 1960 northwest of Ravenscrag, was reported by Robert Folker to the Blue Jay $(19-79)$ the two former records were recalled. The first was a specimen (SMNH) collected at Ravenscrag, September 19, 1919 by Spencer Pearse who noted several on his ranch that year. The seccnd observation, also by Pearse, was made six years later in September, 1925, and is recorded by L. B. Potter (1943. Bird notes from Southwestern Saskatchewan. Can. FieldNat., 57:69-72). 